\title{
Facies analysis, stratigraphic architecture and depositional environments of the Guanajuato conglomerate in the Sierra de Guanajuato, Mexico
}

María Jesús Puy-Alquiza, Raúl Miranda-Avilés, Juan Carlos García-Barragán, Isidro Loza-Aguirre, Yanmei-Li, Gabriela Ana Zanor

María Jesús Puy-Alquiza

yosune.puy155@gmail.com

Raúl Miranda-Avilés Isidro Loza-Aguirre

Yanmei-Li

Departamento de Minas, Metalurgia y Geología, ex hacienda de San Matías, S/N, CP. 36000, Universidad de Guanajuato, Guanajuato, México.

\section{Juan Garlos García Barragán}

Estación Regional del Noroeste, Instituto de Geología, Av. Luis Donaldo Colosio M. esq. Madrid S/N, Campus UNISON, CP. 83000 Hermosillo, Sonora. Universidad Nacional Autónoma de México.

\section{Gabriela Ana Zanor}

División de Ciencias de la Vida, ex Hacienda el Copal km 9 carretera Irapuato-Silao CP., 36500 Irapuato, Universidad de Guanajuato, Irapuato, Guanajuato, Mexico.

BOL. SOC. GEOL. MEX. 2017

VOL. 69 NO. 2

P. $385-408$

\begin{abstract}
The fluvial stratigraphic architecture of the Cenozoic Guanajuato Conglomerate in the Sierra de Guanajuato records part of the infill of continental extensional basins formed after the Laramide Orogeny in the Mesa Central, Mexico. Coarse-grained strata of the Guanajuato Conglomerate represent the deposit of a major channel belt ( 1 to $2 \mathrm{~km}$ wide by $>100 \mathrm{~km}$ long). This channel belt deposits comprises a 2000 m-thick conglomeratic interval interbedded with deposits of matrix-supported gravel, sandstones and mudstones. Facies analysis indicates that Guanajuato Conglomerate were deposited in alluvial fans and fluvial environments. Facies of the Guanajuato Conglomerate include sandy matrix conglomerate (that shows evidence of traction-dominated deposition), debris-flow (Gms) and hyperconcentrated-flow deposits (Sgpc) (interpreted as turbulent gravity flows), and sandstones with plane to horizontal stratification and planar and through cross-stratification, ripples, rain mark, flutes, groove marks, and massive mudstones, mudstones with fine lamination and with desiccation cracks. Based on established facies associations, five architectural elements and 14 facies were determined from nine locations as a result of Eocene post-Laramide sedimentation in the southern Mesa Central. The Guanajuato Conglomerate was divided in two members: Lower and Upper members. The Lower Member unconformably overlies a Mesozoic assemblage (intrusive complex and eruptive sequence assemblage and Guanajuato arc assemblage) and has a thickness between 700 and $1300 \mathrm{~m}$. The Lowe Member is composed of two parts: 1) The basal portion includes conglomerate layers interbedded with sandstones and lava flows. The upper part of the Lower Member conglomerate is caused by debris-flow and hyperconcentrated-flow, major tabular and lenticular sandstone, and siltstone. The Upper Member is characterized by clast-supported conglomerate interbedded with sandstone-mudstone beds. The crudely stratified, imbrications, pebble clusters, coarse to pebbly sandstone, indicate channel lag deposits within a heavy loaded fluvial system. The finegrained sandstone, rain mark, parallel lamination, desiccation cracks, may be interpreted as side bar sediments deposited by shift channels during lowe flow conditions. Sediment distribution patterns and stratigraphic architecture, suggest that the depositional system is a braided fluvial for the Lower Member, while the Upper Member corresponds to alluvial fan environment.
\end{abstract}

Keywords: Guanajuato Conglomerate, facies, architecture, depositional environments, sierra de Guanajuato, Mexico.

\section{RESUMEN}

La arquitectura estratigráfica fluvial del Conglomerado Guanajuato en la Sierra de Guanajuato, registra parte del relleno de las cuencas extensionales continentales, formadas durante el Cenozoico, después de la Orogenia Laramide en la Mesa Central de México. Los estratos de grano grueso del Conglomerado Guanajuato representan el depósito de un canal mayor de 1 a 2 $\mathrm{km}$ de ancho por más de $100 \mathrm{~km}$ de largo. Estos depósitos comprenden un intervalo conglomerático de $2000 \mathrm{~m}$ de espesor intercalado con depósitos de areniscas y lutitas. El análisis de facies indica que el conglomerado Guanajuato se depositó en abanicos aluviales y ambientes fluviales. Las facies del Conglomerado Guanajuato incluyen un conglomerado de matriz arenosa que muestra evidencia de deposición dominada por la tracción, depósitos de flujo de escombros y depósitos de flujo hiperconcentrado, interpretados como flujos de gravedad turbulenta, dichos depósitos se encuentran intercalados por areniscas con estratificación horizontal, estratificación cruzada, ondulitas, marcas de lluvia, flautas, marcas de ranuras, lutitas masivas, lutitas con laminación paralela y grietas de desecación. Con base en la asociación de facies, se determinaron cinco elementos arquitecturales y 14 facies en nueve localidades estudiadas, esto, como resultado de la sedimentación del Eocene post-Laramide en el sur de la Mesa Central. El Conglomerado Guanajuato se divide en dos miembros: miembro inferior y miembro superior. El miembro inferior sobrevace al conjunto Mesozoico (complejo intrusivo y secuencia eruptiva del arco de Guanajuato) presentando un espesor de entre 700 y $1300 \mathrm{~m}$. El miembro inferior se compone de dos partes: 1) La parte basal incluye capas de conglomerado intercaladas con areniscas y flujos de lava. 2) La parte superior constituida por depósitos de flujo de escombros y flujo hiperconcentrado, areniscas y lutitas. El miembro superior se caracteriza por un conglomerado de matriz de clastos soportados intercalados con depósitos de areniscas y lutitas. La estratificación cruzada, imbricación, clastos aislados, areniscas de grano grueso, indican depósitos de un sistema fluvial. La arenisca de grano fino, las marcas de lluvia, la laminación paralela, las grietas de desecación, pueden interpretarse como sedimentos de barras laterales depositados por canales de desplazamiento durante las condiciones de flujo bajo. Los patrones de distribución de los sedimentos y la arquitectura estratigráfica sugieren que el sistema deposicional del Conglomerado Guanajuato corresponde a un ambiente fluvial trenzado para el miembro inferior, mientras que el miembro superior corresponde a un ambiente de abanico aluvial.

Palabras clave: Conglomerado de Guanajuato, facies, arquitectura, ambiente depositacional, sierra de Guanajuato, México. 


\section{Introduction}

The Guanajuato Conglomerate (GC) crops out in the Sierra de Guanajuato (Figure 1), mainly in the Guanajuato mining district. It is located in the transitional zone between two major volcanic provinces of Mexico: the Oligocene Sierra Madre Occidental (SMO) and the Oligocene-Miocene Transmexican Volcanic Belt (TMVB), (Gómez-Tuena et al., 2005; Randall et al., 1994). The volcanic sequences of the southeastern SMO and the Central TMVB are exposed at the Sierra de Guanajuato. These two sequences overly Mesozoic metamorphic and sedimentary rocks (Echegoyen-Sánchez et al., 1970; Dávila and Martínez, 1987). The southern Sierra de Guanajuato includes a thick red bed sequence (Guanajuato Conglomerate), rhyolitic tuffs and lava domes (La Bufa and Chichíndaro Rhyolite), and andesitic lava flows (Cedro Andesite and Calderones). Normal faulting has produced uplifted blocks with NW, N-S and NE trends (Cerca-Martínez et al., 2000). The term "Guanajuato Conglomerate" has been previously used in many publications (Orozco, 1921; Guiza, 1949; Schulze, 1953; Edwards, 1955; Echegoyen-Sánchez et al., 1970; Aranda-Gómez et al., 1989; Randall et al., 1994; Aranda-Gómez and Mc Dowell, 1998; Aranda-Gómez et al., 2003). However, no detailed stratigraphic architecture and a depositional model have been established. In this work, we analyzed the facies geometry and the relationships between the geometry and stratigraphic arrangement to understand the evolution of accommodation space after the Laramide Orogeny in this region of the Sierra de Guanajuato.

\section{Geological setting}

The Sierra de Guanajuato is a NW-SE-oriented chain with elevations between 2000 and $2500 \mathrm{~m}$. This range lies in the central segment of the Guerrero terrane constituted by arc and basin sequences, particularly the Mexican late Jurassic-early
Cretaceous Alisitos-Teloloapan arc (Tardy et al., 1992). In the southwestern front tip of the Sierra de Guanajuato the Bajío fault, marks the northern boundary El Bajío depression (Aranda Gomez et al., 1989; Nieto-Samaniego, 1992; Botero-Santa et al., 2015). The Bajío fault is a normal fault that consists of two large segments. The easternmost segment extends from Celaya to Irapuato; it strikes nearly E-W and forms the El Bajío Basin. In the footwall of the El Bajío fault, there are two groups of faults, which strike NW-SE and NE-SW and produce zigzag pattern in the fault trace. The second segment of the Bajío fault forms the S-W escarpment of the Sierra de Guanajuato, which is located in the raised block (Lara-Hernández, 1985). The displacement is $850 \mathrm{~m}$, measured in Oligocene volcanic units (Nieto-Samaniego et al., 2005). The volcanic sequences of the southeastern SMO and the central TMVB are composed of silicic ignimbrite, rhyolitic lava domes (Oligocene and Miocene), basalt and andesite of middle Oligocene to late Pliocene (Ferrari et al.,1999; Aguirre-Díaz et al., 1998; Lapierre et al., 1992; Ortiz-Hernández et al., 1992; Aranda-Gómez et al., 1989). In the Sierra de Guanajuato, two Mesozoic petrotectonic assemblages are recognized: 1. An intrusive complex and eruptive sequence assemblage and 2. The Guanajuato arc assemblage (El Paxtle and Arperos Basin assemblages) (Martini et al., 2013). The Guanajuato Conglomerate (GC) and the Cenozoic volcanic cover the Mesozoic assemblage. According to Aranda-Gomez et al. (1989), continental Eocene conglomerates were deposited as alluvial fans at the foot of fault blocks. The regional distribution of these deposits suggests that El Bajío fault and La Aldana fault already existed during the Eocene.

\section{Methods}

Facies, facies associations, architectural elements, bounding surfaces and analysis of paleocurrent directions were studied. The sedimentology of the Guanajuato Conglomerate (GG), was analyzed in 


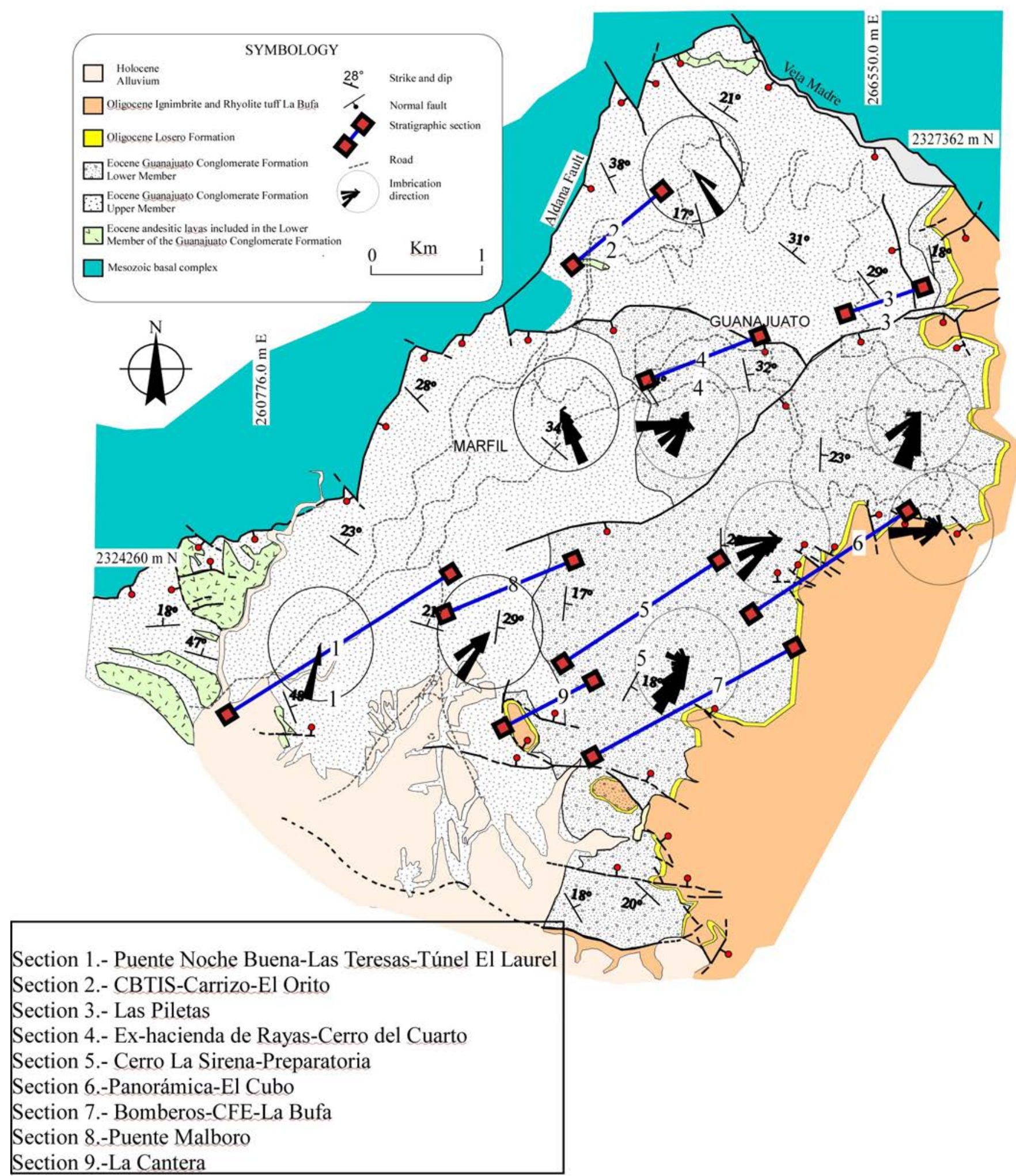

Figure 1 General map of Guanajuato area in central México. La Aldana and Veta Madre faults bounds the north and northwestern margin of the Cenozoic fluvial basin. The Oligocene volcanic rocks cover the southeastern side of the study area. 
nine stratigraphic sections (Figure 1) along small streams (e.g. Las Piletas, El Orito, and Malboro) and road cuts (Puente Noche Buena, Las Teresas, CBTIS, Carrizo, ex-hacienda de Rayas, Cerro del Cuarto, Cerro La Sirena, Preparatoria, Panorámica El Cubo, Bomberos, CFE, La Bufa and La Cantera). Stratigraphic sections were measured in nine localities: Puente Noche Buena-Las Teresas-Túnel El Laurel (section 1), CBTIS-Carrizo-El Orito (section 2), Las Piletas (section 3), Ex-hacienda de Rayas-Gerro del Cuarto (section 4), Cerro La Sirena-Preparatoria (section 5), Panorámica-El Cubo (section 6), Bomberos-CFE-La Bufa (section 7), Puente Malboro (section 8) and La Cantera (section 9) (Figure 1). In each locality, we made detailed sedimentological lithofacies and facies associations using a modified lithofacies and architectural Miall's (1996) classification scheme. The reconstruction of sedimentary bodies (architectural elements), and their bounding surfaces, including their lateral variability, were derived from interpretation of outcrop profiles and photomosaics of lateral continuous outcrops using the architectural elements (Miall, 1996). Detailed columnar sections were constructed based on textures, sedimentary structures and their association. Pebble composition was studied in all sections. The composition was determined directly in the field by counting pebbles of different lithology occurring within a $50 \times 50 \mathrm{~cm}^{2}$ grid, having individual $10 \mathrm{x}$ $10 \mathrm{~cm}^{2}$ square. The grid was moved laterally on the same bed at least five times in order to have a minimum count of 100 pebbles. A total of 900 clasts were counted in nine sections. Pebble compositions were plotted in a pie diagram of clastic compositions and located in the columnar sections. More than 218 paleocurrent indicators were measured in imbricated pebbles in conglomerates in the nine localities studied, to distinguish dispersal patterns.

\section{Results and discussion}

\subsection{DESGRIPTION OF GUANAJUATO GONGLOMERATE (GC)}

The Guanajuato Conglomerate (GC) is considered of Eocenic age (Ferrusquía-Villafranca, 1987; Aranda-Gómez and McDowell, 1998) with a thickness between 1500 and $2000 \mathrm{~m}$, and was divided by Edwards (1955) in two members. The Lower member unconformably overlies a Mesozoic assemblage and has a thickness between 700 to $1300 \mathrm{~m}$. The Lower member is composed of two parts: 1) basal conglomerate and sandstone intercalated with andesitic lava flows (Figure 2 and 3). The basal part of the Lower member (145 m) was measured in section 1, and section 2, located in the western part of the study area (Figure 1). Outcrops in these sections consist of clast-supported conglomerate with predominant volcanic clast (43\%), diorites $(22 \%)$, and minor proportion of granitic $(6 \%)$, Quartzites $(9 \%)$, metasediments $(16 \%)$ and sandstone clast (4\%); 2) the top part of the Lower Member is a clast-supported and matrix-supported conglomerates and sandstones intercalated with mudstones (Figure 2 and 3). It is located in the northeastern part of the study area, in section 3, section 4 and section 5, (Figure 1). Maximum thicknesses of $1000 \mathrm{~m}$ consist of clast-supported conglomerate with volcanic, metasediments, granite and limestone clasts. These deposits conformably on the basal part of the Guanajuato conglomerate. The Upper Member varies from 170 to $1300 \mathrm{~m}$, toward the southeast. The contact between the Lower and Upper Member is an erosional unconformity of undetermined age (Edwards, 1955). Outcrops in section 6, section 7, section 8 and section 9 located in the northwest area consists of clast-supported conglomerate with a higher granite clast than volcanic and metasediments. 


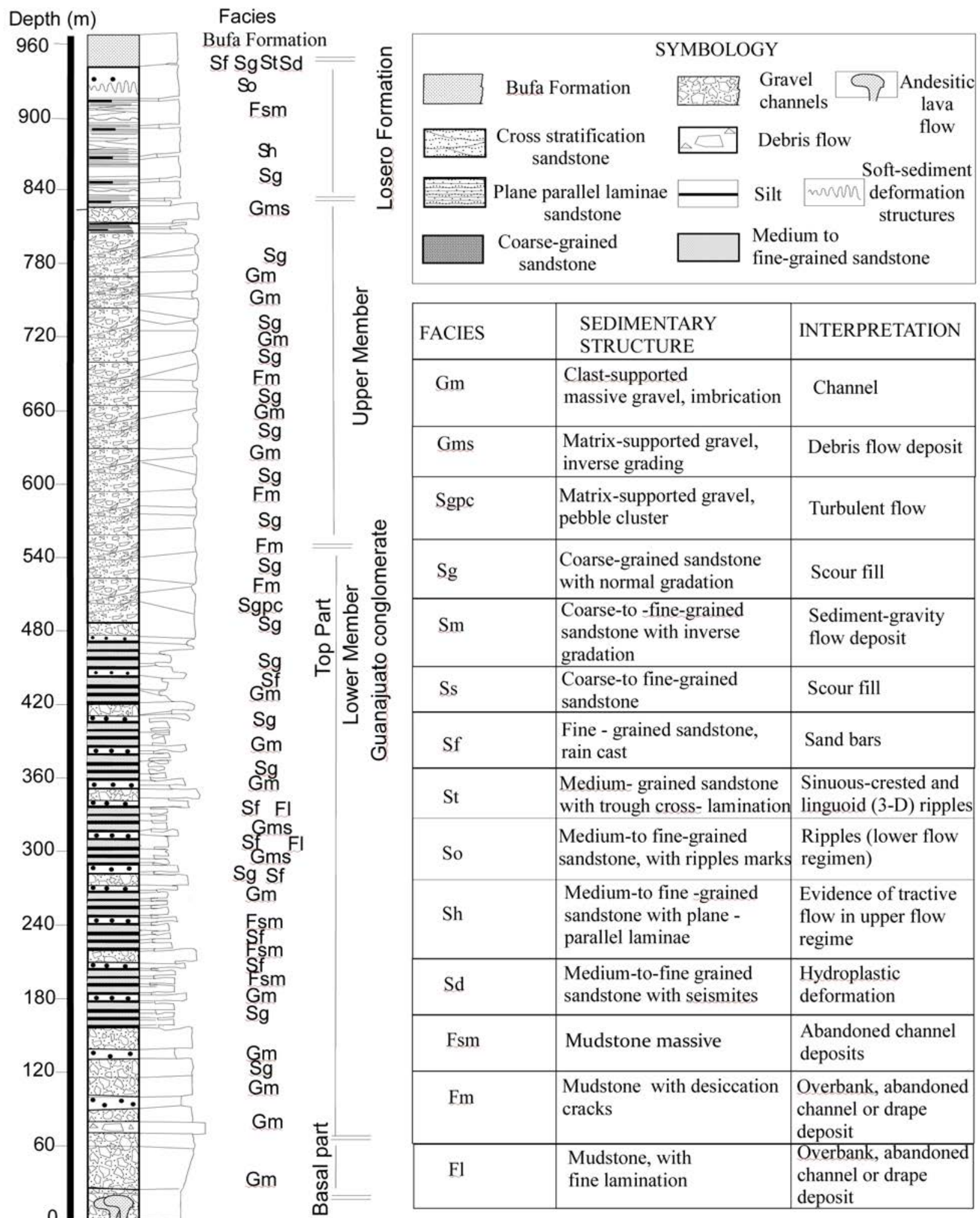

Figure 2. Columnar section of the Guanajuato Conglomerate. 

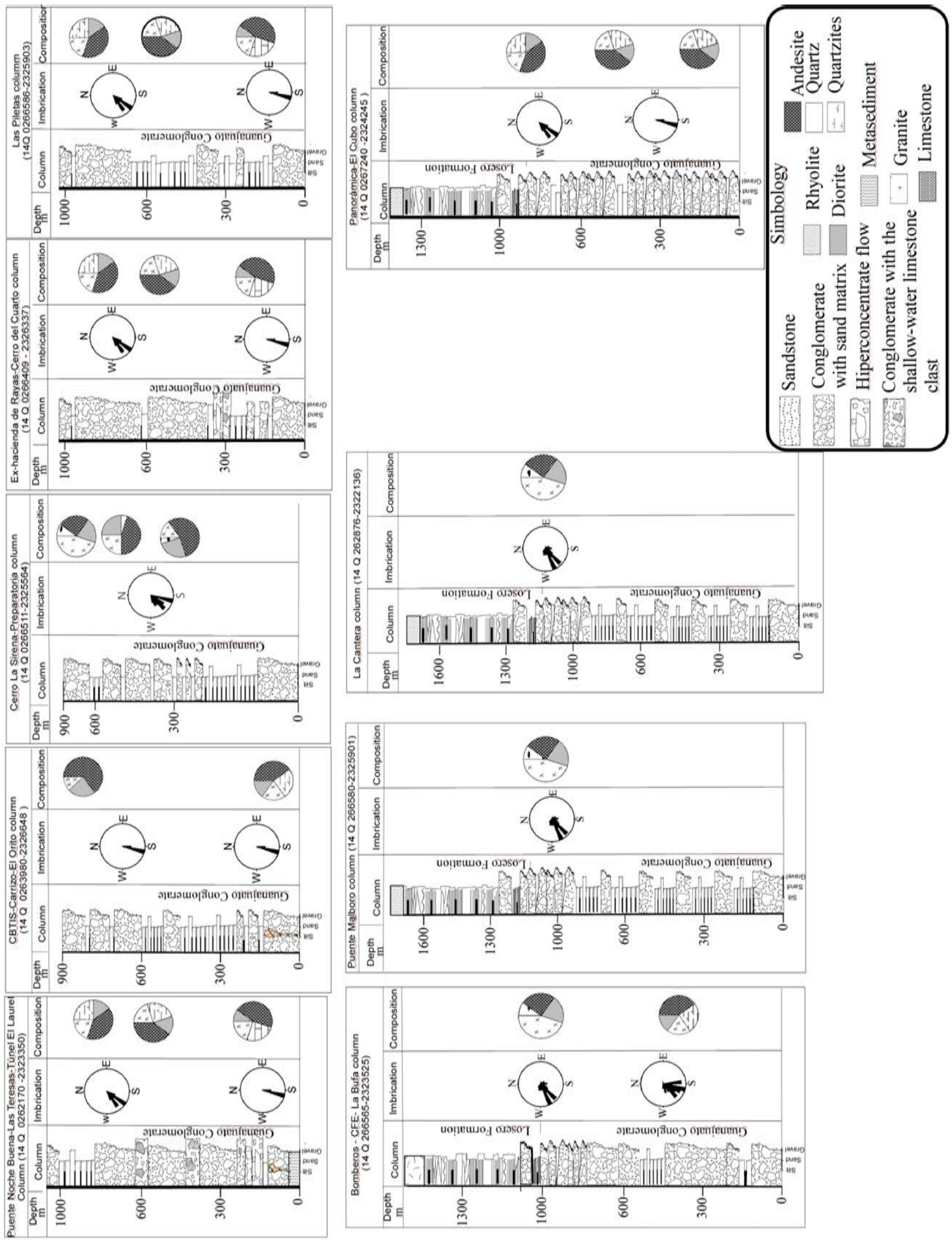


\subsection{SEDIMENTARY FAGIES, ASSOGIATION AND INTERPRETATION}

Facies description of the Guanajuato Conglomerate was carried out using a modified version of Miall's (1978, 1996) lithofacies classification scheme. The identification of 14 facies (Table 1) was based on their texture, framework, sedimentary structures, external geometry, and nature of contacts. Facies of the Guanajuato Conglomerate are highly variable within and between individual outcrops. The facies were dependent upon distance between sources and depositional sites, and specific environments of deposition, at least two of which were recognized. These facies can be integrated into seven distinct facies associations (G1, G2, S1, S2, S3, F1 and F2) (Table 1). In general, these facies associations are similar to those typical of humid subaerial alluvial fans and braided deposits (i.e. the Okavango fan, Rozel Conglomerate Formation, Copper River fan-delta). Most of them are conglomerate to sandstone-dominated. Mudstone-dominated facies only crop out locally.

\subsubsection{BASAL-PART OF THE LOWER MEMBER OF THE GUANAJUATO CONGLOMERATE}

\subsubsection{Glast-supported Gravel Bed (G1).} These facies associations are characterized by clast-supported conglomerate (Gm facies) with thickness from 0.5 to $1 \mathrm{~m}$, interbedded with sandstone (Ss facies). It has a maximum thickness of $100 \mathrm{~m}$ and is located in section 2, in the western part of the study area (Figure 1). These facies associations consists of granule to pebble-size grains, (largest clast is $10 \mathrm{~cm}$ in diameter) moderately sorted, thick-bedded to massive conglomerate with calcite and iron oxide, characterized by ungraded clast-supported conglomerate beds (Figure 4). In section 2, the andesitic lava flows are red brownish. These lava flows are within the conglomerate $(\mathrm{Gm})$. Conglomerate strata have a concave erosive base. Outcrops of lava flows are located southwest of the city of Guanajuato to the Aldana fault, which in turn is contact with Esperanza Forma- tion and the Guanajuato Conglomerate (Figure 1). The conglomerates are polymictic, massive and texturally immature. The clast-supported massive conglomerate units are interpreted as small channel lag or longitudinal braided bars of low sinuous streams (Jo et al., 1997; Blair, 1999). The bed geometry represents gravel sheets or low relief longitudinal fluvial bars. Clast-supported granule and pebble probably reflect tractional transport during aggradation of longitudinal bars (Miall, 1977, 1978; Rust, 1978).

4.2.1.2. Scour-Fill Sand (S1). These facies associations are characterized by sandstones facies (Sg and $\mathrm{Ss}$ ). The $\mathrm{Sg}$ and $\mathrm{Ss}$ facies consist of sand, moderately to poorly sorted, subangular to subrounded, coarse to medium grained with normal gradation. Sand detritus is dominantly of quartz, feldspar, lithics and minor, dark-heavy minerals. Outcrops of sandstones facies in display massive bedding. The basal contact of the tabular sandstone is planar or gently erosional with a thickness between 0.3 to $1 \mathrm{~m}$ (Figure 4), with a horizontal to sub-horizontal lamination, and low-angle cross-stratification.

The discontinuous nature of sandstones facies $(\mathrm{Sg}$ and $\mathrm{Ss}$ ), correspond to scour-fill sand with tabular and lenticular shape interpreted as fluvial channel deposits (Miall, 1996). In accordance with Andrews (1979), the scour-fill refers to fluctuations in the vertical position of an alluvial stream-bed during a flood event. The fluctuations occur in response to the entrainment (or scour) and deposition (or fill) of bed material and reflect redistribution of sediment within the channel.

\subsubsection{TOP-PART OF THE LOWER MEMBER OF THE GUANAJUATO CONGLOMERATE}

\subsubsection{Glast-supported Gravel Bed (G1).} Facies associations G1 are characterized by conglomerate $(\mathrm{Gm})$ with thicknesses from 0.1 to $2 \mathrm{~m}$, which can be laterally traced more than $50 \mathrm{~m}$, and subordinate sand facies $\mathrm{Sg}$, and $\mathrm{Ss}$ (Figure 4). The conglomerates are red and consist of granule to 
Table 1. Description and interpretation of the facies of the Guanajuato Conglomerate

\begin{tabular}{|c|c|c|c|c|c|}
\hline $\begin{array}{c}\text { Facies } \\
\text { associations }\end{array}$ & & Facies & Sedimentary structures & Thick & Interpretation \\
\hline G1 & $\mathrm{Gm}$ & 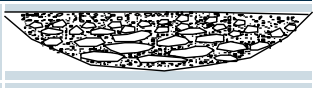 & $\begin{array}{l}\text { Clast-supported, massive gravel, } \\
\text { imbrication. }\end{array}$ & $2 \mathrm{~m}$ & Channel \\
\hline \multirow{2}{*}{ G2 } & Gms & ros & Matrix-supported gravel, inverse grading. & $1 \mathrm{~m}$ & Debris flow deposit \\
\hline & Sgpc & 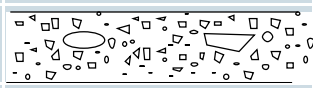 & $\begin{array}{l}\text { Clast-supported gravel, and largest } \\
\text { boulders. }\end{array}$ & 0.3 a $1 \mathrm{~m}$ & Hyperconcentrated flow \\
\hline \multirow{2}{*}{ S1 } & $\mathrm{Sg}$ & 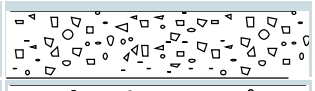 & Sand coarse, massive. & 0.3 a $1 \mathrm{~m}$ & Scour fill \\
\hline & Ss & $\because \because 00 \div:=$ & Sand fine to coarse, shallow scours. & 0.3 a $1 \mathrm{~m}$ & Scour fill \\
\hline $\mathrm{S} 2$ & $\mathrm{Sm}$ & 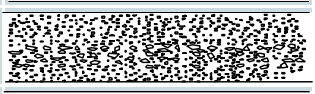 & $\begin{array}{l}\text { Sand fine to coarse, massive, inverse } \\
\text { grading. }\end{array}$ & 0.3 a $1 \mathrm{~m}$ & Sediment-gravity flow deposit \\
\hline \multirow{5}{*}{ S3 } & Sf & & Sand fine. & 0.3 a $1 \mathrm{~m}$ & Sand bars \\
\hline & $\mathrm{Sr}$ & & Sand very fine to coarse, Ripples. & 0.3 a $1 \mathrm{~m}$ & Ripples (lower flow regimen) \\
\hline & St & $=0$ & Sand medium to coarse, trough cross bed. & 0.3 a $1 \mathrm{~m}$ & $\begin{array}{l}\text { Sinuous-crested and linguoid (3-D) } \\
\text { dunes }\end{array}$ \\
\hline & $\mathrm{Sd}$ & $\because \because \because: \because::=$ & Sand very fine to coarse, seismites. & 0.3 a $1 \mathrm{~m}$ & Sand bars \\
\hline & Sh & 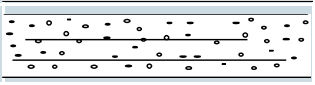 & $\begin{array}{l}\text { Sand very fine to coarse, horizontal } \\
\text { lamination. }\end{array}$ & 0.3 a $1 \mathrm{~m}$ & Plane-bed flow \\
\hline F1 & Fsm & 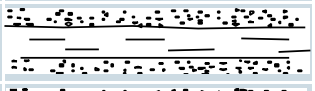 & Silt, massive. & $1 \mathrm{~cm}$ & Abandoned channel deposits \\
\hline \multirow{2}{*}{$\mathrm{F} 2$} & Fm & 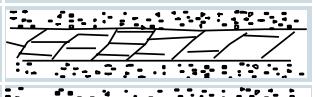 & Mud, massive, desiccation cracks. & $1 \mathrm{~cm}$ & Overbank \\
\hline & Fl & 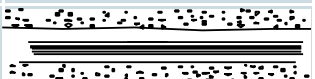 & Mud, fine lamination. & $3 \mathrm{~cm}$ & Overbank \\
\hline
\end{tabular}

pebbly size grains, (longest clast diameter is $10 \mathrm{~cm}$ ) moderately sorted, massive conglomerate with subrounded clasts, sandy matrix and unconsolidated to poorly cemented. Ungraded, clast-supported conglomerate beds (Figure 4) characterize facies G1. The G1 are interstratified with facies Sg, SS and facies Fm. The granule and pebble content exceeds 50 percent.

The clast-supported massive conglomerate units were deposited as small channel lag bodies or longitudinal braided bars of low sinuous streams. Conglomerate with moderately developed clast imbrications may result incised-channel gravel bed sedimentation under accreting low to waning-energy flows (Jo et al., 1997; Blair, 1999). Clast-supported granule and pebble probably reflect tractional transport during aggradation of longitudinal bars (Miall, 1977, 1978; Rust, 1978. The presence of imbrication suggests an upper flow regime. Deposits of the facies Gm are interpreted as mixed in-channel sediments (Miall, 1977, 1978). The interstratification of sandstone beds and siltstone lenses is common in braided systems (Rust and Koster, 1984). Architectural elements include channels $(\mathrm{CH}, \mathrm{HO})$ and poorly developed downstream- accretion macroforms (DA) (Figure 4).

\subsubsection{Matrix-supported Gravel Bed (G2).} Facies associations $\mathrm{G} 2$ are characterized by facies Gms and Sgpc. These facies consists of lenses and beds of cobbles and boulders that are red, massive to crudely stratified, matrix to clast-supported, poorly sorted, and unconsolidated to poorly cemented. The thickness ranges between 0.3 to 1 $\mathrm{m}$, which can be laterally, traced more than $10 \mathrm{~m}$. The beds are massive and the imbrication is ab- 

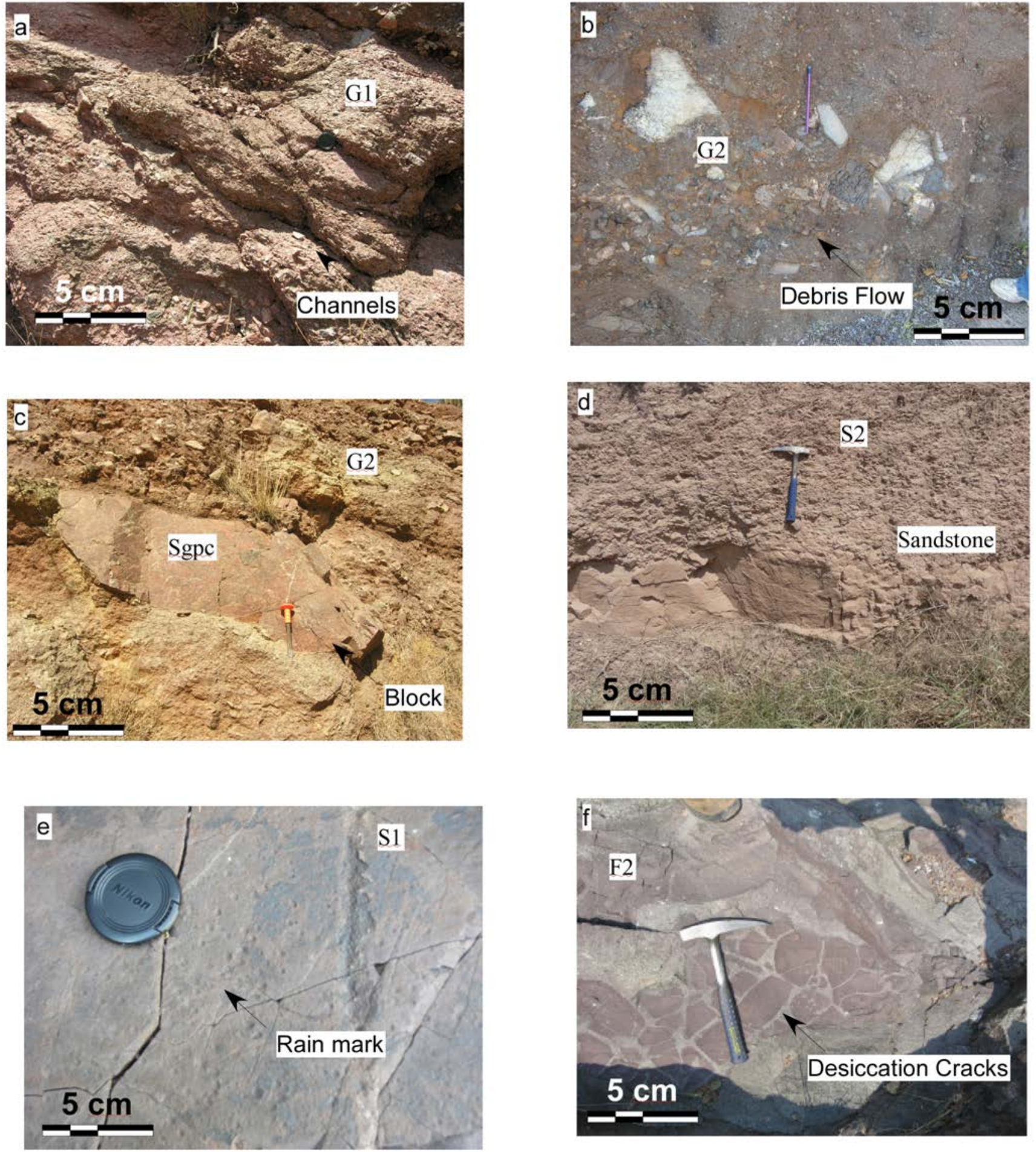

Figure 4 Facies associations photographs from the lower member of the Guanajuato Conglomerate. (a) Clast-supported Gravel Bed (G1), (b, c) Matrix-supported Gravel Bed (G2), (d, e) Massive sand (S2), Scour-Fill Sand (S1), (f) Laminated mudstone and desiccation cracks (F2). 
sent (Figure 4). Beds of this facies have sharp but non-erosional relationships with underlying beds. The Sgpc facies includes large boulders (1 m long) of granite and rhyolite.

Deposits of facies associations G2 are interpreted as in-channel and outwash sediments deposited during major floods. Matrix-supported cobble and boulder-dominated facies deposits commonly reflect mass transport and deposition as debris flow deposits (Bull 1972; Miall 1977, 1978). In subaerial environments, debris flows are commonly into hyperconcentrated flows when they encounter a streamflow (Pierson and Costa, 1987; Costa, 1988). A transition facies is produced during these events, comprising both debris-flow and hyperconcentrated flow deposits in one sedimentation unit (Scott et al., 1995; Sohn, 1999). Dasgupta (2007) suggested that these types of facies could be found in an alluvial fan system. Liquefaction is a common mechanism for the generation of hyperconcentrated density flows and is considered the most frequent mechanism for triggering subaerial debris flows (Iverson et al., 1997). The lack of grading can also be explained as a result of reworking of deposits at the head of flow because of fast speed downslope movement, causing syn-depositional mixing and churning and rapid deposition as flow competence declines (Hein, 1982). Hence, this facies are the proximal part of the fan a sudden break in the slope generated hyperconcentrated flows in small basins with shallow water depths, particularly in tectonically active settings (Mutti et al., 1996). Architectural elements include sediment gravity-flow deposits (SG).

4.2.2.3. Scour and-Fill Sand (S1). The major tabular and lenticular sandstone $\mathrm{S} 1$ is common in the Guanajuato Conglomerate. They are composed of Sg, Ss, Sh, and Sf facies (Table 1, Figure 4). The Sg and Ss sandstone beds are massive. The sand grains are angular to subround, and poorly to moderately sorted, composed of quartz, feldspar, lithics and minor, dark, heavy minerals. The matrix is silty. Facies associations S1 occur as single and multilayered units, which commonly ex- ceed hundreds of meters in lateral extent. Tabular sandstone bodies have thickness ranges from 0.3 to $1 \mathrm{~m}$. Poorly developed, coarse to pebbly sandstone facies commonly overlies the conglomerate and grades vertically into coarse to medium-grained sandstones. The facies Sh and Sf (light brown, or red) consist of either poorly sorted, medium to very coarse-grained sandstone that include granules and minor pebbles or well-sorted, fine to medium-grained sandstone. Lower and upper contacts of rock units and beds are either erosional or non-erosional. Strata show tabular geometry. Parallel lamination and rain casts are common primary structures. Thin strata of mudstone and siltstone separate the successive sandstone bodies (Figure 4).

These facies associations are interpreted as mixed in-channel sediments. Deposition of parallel lamination, stratified, sand-dominated lenses and beds reflect aggradation of transverse and longitudinal sand bars and dunes (Miall 1977, 1978). Architectural elements include sandy bedforms (SB).

4.2.2.4. Massive sandstone (S2). Facies associations $\mathrm{S} 2$ are characterized by facies $\mathrm{Sm}$, and Ss. Sandstone beds are massive. The sand grains are angular to subrounded, and poorly to moderately sorted. The thickness ranges from 0.3 to $2 \mathrm{~m}$. Scattered pebbles ranging from $1 \mathrm{~cm}$ to $2 \mathrm{~cm}$ in diameter are present. The sandstone is friable, consolidated and the base of this sandstone is abrupt (Figure 4).

Massive sandy beds of facies Sm and Ss might be formed in response to sediment gravity flows (McCabe, 1977; Jones and Rust, 1983) and interpreted as result of transport and deposition by short-lived mass flows. Sediment gravity-flow deposits indicate non-cohesive gravity-flow deposition. Their presence within the channel fills probably records channel bank instability and slumping. Sediment Gravity-Flow deposits (SG) is the architectural element of the S2.

4.2.2.5. Laminated mudstone and desiccation cracks (F2). Facies associations F2 are 
characterized by facies Fm and Fl; consist of alternating massive to laminated, brown and red siltstone and dark red claystone with desiccation cracks. The beds are a few millimeters to five centimeters thick. Mud facies tend to be discontinuous in the surface and commonly grade down into muddy-sand (Figure 4).

The fine-grained sediments and generally good sorting indicate that this facies resulted primarily from suspension deposition in standing or slow-moving waters, probably in an overbank and possibly in a backwater swamp or lacustrine setting such as described for similar facies by Miall (1977, 1978). Overbank Fine (FF) is the architectural element of F2.

\subsubsection{UPPER MEMBER GUANAJUATO CONGLOMERATE.}

\subsubsection{Clast-supported Gravel Bed (G1).} Facies associations G1 are characterized by ungraded, clast-supported gravel beds (Table 2 and Figure 5) with subrounded clasts. Pebbles are usually of size between 0.5 and $2 \mathrm{~cm}$. Individual beds are up to $1.3 \mathrm{~m}$ thick, with sharp bases. This facies are underlain by coarse-grained gravel and/ or coarse-grained sandstone. This facies association appears massive, occasionally with preserved coarser pebble layers enclosed within finer beds, which marks changes in hydrodynamic conditions and the multi-phase nature of the deposition. The matrix of the conglomerate is mainly composed of moderately sorted, coarse-grained sandstone to fine-grained conglomerate.

The absence of sedimentary structures, and the poor sorting and mixing of fine and coarse material suggest that G1 was deposited by gravity flow, probably of a debris flow nature. The lack of grading can be explained as a result of reworking of deposits at the head of a flow by its more turbulent movement, causing syn-depositional mixing and churning and rapid deposition as flow competence declines (Hein, 1982). Architectural elements include channels $(\mathrm{CH}, \mathrm{HO})$ and poorly developed Downstream-Accretion Macroforms (DA).
4.2.3.2. Scour-Fill Sand (S1). Facies associations $\mathrm{S} 1$ include facies $\mathrm{Sg}$ and $\mathrm{Ss}$ (Figure 5) which are composed of poorly sorted, coarse- and medium-grained, sand and abundant clasts. Lower and upper contacts of beds are sharp and erosional. Beds exhibit tabular to lenticular geometry. Tabular sandstone bodies have a thickness from 0.3 to $1 \mathrm{~m}$. Sole markings, including flute marks and groove marks, are common in the base of the beds. They are remarkably straight and some of them are continuously exposed all along the bedding plane.

The characteristics of these facies indicate rapid deposition of poorly sorted, coarse bed load (Rust, 1978b). Flute and groove marks are produced by the flow of currents on soft and/or saturated mud (Crowell, 1955; McBride, 1962). The flutes represent sediments that filled depressions on subjacent bedding plane. They are erosive structures that are produced by movements of a fluid over a cohesive substrate and are caused by erosion of freshly deposited mud (Ricci-Lucchi, 1995). Architectural elements include Sandy bedforms (SB).

4.2.3.3. Sand Ghannels (S3). The facies associations $\mathrm{S} 3$ are constituted by facies $\mathrm{Sf}, \mathrm{So}, \mathrm{St}$, Sh and Sd (Figure 5). It consists of brown to red, fine to coarse-grained, moderately to poorly sorted, subangular to subrounded sand, and unconsolidated to weakly cemented. Sandstones facies display massive bedding, plane and horizontal stratification and planar and trough cross-stratification in $10 \mathrm{~cm}$ to $1 \mathrm{~m}$ thick tabular sets. The facies $\mathrm{St}$ consist of either poorly sorted, medium-grained to pebbly sandstone, or moderately sorted, medium to coarse-grained sandstone. Lower and upper contacts of co-sets and sets are sharp and erosional. The facies Sh (light brown, or red) consists of either poorly sorted, medium to very coarsegrained sandstone containing granules and minor pebbles or well-sorted, fine to medium-grained sandstone. Lower and upper contacts of rock units and beds are either erosional or non-erosional. Strata show tabular geometry with ripples, rain casts and soft-sediment deformation. Sandstones 
Table 2. Description and interpretation of the facies in the Upper Member.

\begin{tabular}{|c|c|c|c|c|}
\hline Facies associations & & Facies & Sedimentary structures & Thick \\
\hline G1 & $\mathrm{Gm}$ & & Imbrication & $2 \mathrm{~m}$ \\
\hline G2 & Sgpc & 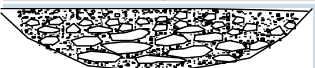 & --------------------' & $1 \mathrm{~m}$ \\
\hline S1 & $\mathrm{Sg}$ & 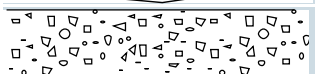 & Scour shallow & 0.1 a $0.3 \mathrm{~m}$ \\
\hline
\end{tabular}
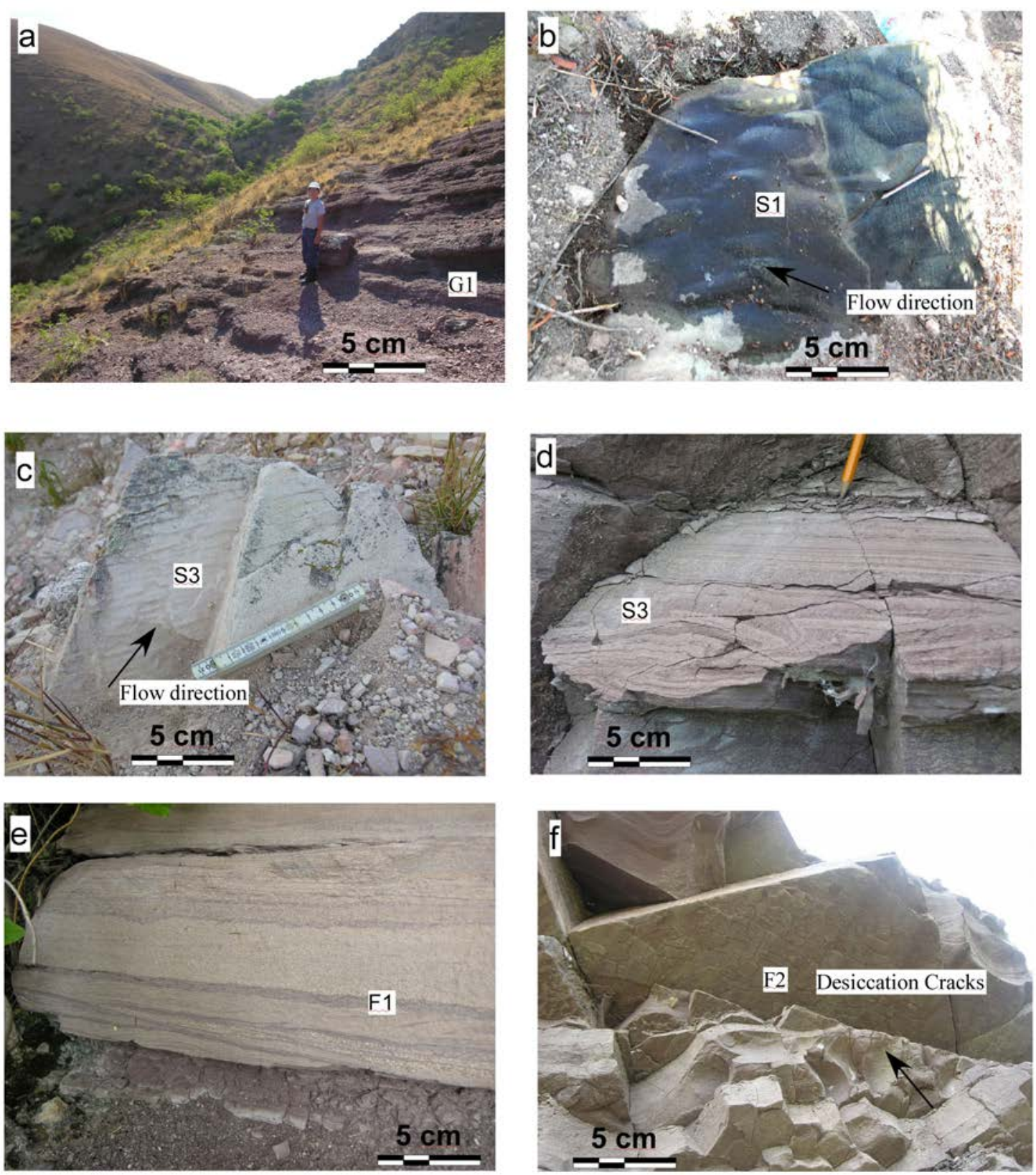

Figure 5 Facies associations photographs from the upper member of the Guanajuato Conglomerate: (a) Clast-supported Gravel Bed (G1), (b) Scour-Fill Sand (S1), (c, d,) Sand Channels (S3), (e) Massive mudstone (F1), (f) Laminated mudstone and desiccation cracks (F2). 
facies commonly grade upwards into facies associations F1 and grade downwards into G1. Sand is composed dominantly of quartz and feldspar grains, and with lesser granitic, andesitic, rhyolite, and phyllite fragments.

The fine to coarse-grained sand, and primary sedimentary structures are consistent with migration and aggradation of ripples and plane beds (Miall, 1977, 1978). The discontinuous nature of sandstones facies suggests a fluvial channel sandy deposits (Harms et al., 1982). The presence of soft-sediment deformation indicates periodic rapid accumulation of sediments. Architectural elements include Sandy bedforms (SB).

\subsubsection{Massive mudstone $(\mathrm{F} 1)$. This facies} association consists of interbedded laminations of siltstone and claystone (F1), (Figure 5). The thickness of sharp-based strata varies from $5 \mathrm{~cm}$ to 20 $\mathrm{cm}$ and are interbedded with minor, sharp-based, normally graded, fine-grained sandstone beds. They often rest on an erosional surface or on medium to coarse-grained sandstone.

Sediments of this facies were deposited mostly from suspension, but also by low velocity unidirectional currents. They most probably represent an abandoned channel fill (Miall, 1977, 1978). Architectural elements include Overbank Fine (FF).

\subsubsection{Laminated mudstone and desicca-} tion cracks (F2). Facies associations F2 are characterized by facies Fm and $\mathrm{Fl}$ (Figure 5). It consists of alternating massive to laminated, brown and red siltstone, and dark brown claystone with desiccation cracks. The beds are a few millimeters to five centimeters thick. Mud facies tend to be discontinuous in the surface and commonly grade down into muddy-sand and sandy-gravel facies.

The fine grain size and generally good sorting indicate that this facies resulted primarily from suspension deposition in standing or slow-moving waters, probably in an overbank and possibly in a backwater swamp setting such as described by Miall $(1977,1978)$. Architectural elements include Overbank Fine (FF).

\section{Analysis of the sedimentary architectural elements}

Five architectural elements were recognized: channels $(\mathrm{CH}, \mathrm{HO})$, sediment gravity flow deposits (SG), sandy bedforms (SB), downstream-accretion macroforms (DA) and flood plain fines (FF). Not all of these features were observed at each outcrop (Table 3). These elements defined by their geometries and bounding surfaces (Miall, 1996), form the basis for interpreting depositional environments.

\section{GH: GHANNELS, HO: GHANNELS FILLS (FIGURE 6).}

Channel deposits comprise facies associations G1, S1 and S3. In the Lower and Upper Member of the Guanajuato Conglomerate, the channel deposits have sharp erosional bases, often erode sand bedforms and other channels. Their geometry is of the concave channel, locally forming a multistory channel geometry. The channel thicknesses vary from $1 \mathrm{~m}$ to $2 \mathrm{~m}$ in most cases. Channel widths vary between $2 \mathrm{~m}$ to $4 \mathrm{~m}$.

Channels comprising facies associations G1, S1 and S3 record channel deposition. The presence of coarse-grained conglomerates may indicate a sudden increase in velocity, lateral migration of channels is a typical feature. Most channels have a multi-story and multi-lateral nature.

\section{SG: SEDIMENT GRAVITY-FLOW DEPOSITS (FIGURE 7)}

Sediment gravity-flow deposits consists of facies associations G2 and S2, matrix supported, massive gravels. They have sharp, erosional bases and the geometry of elongate lobes. They are underlain by gravel or sand bedforms, and they occur within channel deposits.

These deposits occur commonly in the Lower Member of the Guanajuato Conglomerate. Sediment gravity-flow deposits thicknesses are up to $0.5 \mathrm{~m}$ in most cases. The width varies between 0.5 $\mathrm{m}$ to $1 \mathrm{~m}$.

Sediment gravity-flow deposits indicate non-cohesive, gravity-flow deposition. Their presence with- 
Table 3. Architectural elements in Guanajuato Conglomerate.

\begin{tabular}{|c|c|c|c|c|c|c|c|}
\hline Group & $\begin{array}{l}\text { Bounding } \\
\text { Surfaces }\end{array}$ & $\begin{array}{c}\text { Facies } \\
\text { associations }\end{array}$ & $\begin{array}{l}\text { Architectural } \\
\text { Element }\end{array}$ & Code & $\begin{array}{l}\text { Geometry and } \\
\text { relations }\end{array}$ & $\begin{array}{l}\text { Order Bounding } \\
\text { Surfaces }\end{array}$ & Scheme \\
\hline \multirow[t]{2}{*}{1} & \multirow[t]{2}{*}{3} & S1 & \multirow{2}{*}{ Sandy bedforms } & \multirow{2}{*}{ SB } & \multirow{2}{*}{ Sheets, minor bars } & \multirow{2}{*}{$\begin{array}{l}\text { First and second- } \\
\text { order, ripple, cross } \\
\text { and horizontal } \\
\text { lamination }\end{array}$} & 伩Sh \\
\hline & & S3 & & & & & \\
\hline \multirow{2}{*}{1} & \multirow{2}{*}{2} & F1 & \multirow{2}{*}{$\begin{array}{l}\text { Overbank Fine } \\
\text { Flood plain fines }\end{array}$} & \multirow{2}{*}{$\mathrm{FF}$} & \multirow{2}{*}{$\begin{array}{l}\text { Sheet-like units } \\
\text { interbeded with } \\
\text { element SB }\end{array}$} & \multirow{2}{*}{$\begin{array}{l}\text { First-order, fine } \\
\text { lamination }\end{array}$} & $=\mathrm{SB}$ \\
\hline & & F2 & & & & & \\
\hline \multirow{2}{*}{4} & \multirow{2}{*}{1} & G2 & \multirow{2}{*}{$\begin{array}{l}\text { Sediment Gravity- } \\
\text { Flow deposits }\end{array}$} & \multirow{2}{*}{ SG } & \multirow{2}{*}{$\begin{array}{l}\text { Elongate lobes, sheet } \\
\text { interbedded with } \\
\text { element SB }\end{array}$} & \multirow{2}{*}{$\begin{array}{l}\text { Second-order } \\
\text { debris flow }\end{array}$} & 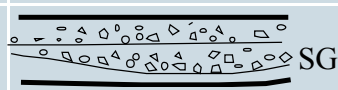 \\
\hline & & S2 & & & & & \\
\hline \multirow{3}{*}{5} & \multirow{3}{*}{3,4} & G1 & \multirow{3}{*}{$\begin{array}{l}\text { Downstream- } \\
\text { Accretion } \\
\text { Macroforms }\end{array}$} & \multirow{3}{*}{ DA } & \multirow{3}{*}{$\begin{array}{l}\text { Sheet-like units } \\
\text { interbedded with } \\
\text { element SB } \\
\text { interbedded with } \\
\text { element SB }\end{array}$} & \multirow{3}{*}{$\begin{array}{l}\text { Third-and fourth, } \\
\text { lens on flat }\end{array}$} & $\mathrm{SB}$ \\
\hline & & S1 & & & & & $\mathrm{H}$ \\
\hline & & S3 & & & & & \\
\hline 6 & 10 & G1 & Channels & $\mathrm{HO}$ & $\begin{array}{l}\text { Channels Fills with } \\
\text { asymmetric fill }\end{array}$ & $\begin{array}{l}\text { Fourth-order, } \\
\text { Channels Fills }\end{array}$ & 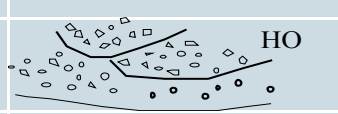 \\
\hline \multirow{3}{*}{7} & \multirow{3}{*}{2} & G1 & \multirow{3}{*}{ Channels Fills } & \multirow{3}{*}{$\mathrm{CH}$} & \multirow{3}{*}{$\begin{array}{l}\text { Channels, concave-up } \\
\text { erosional base }\end{array}$} & \multirow{3}{*}{$\begin{array}{l}\text { Fifth-order, } \\
\text { Channels }\end{array}$} & \multirow{3}{*}{$\mathrm{CH}$} \\
\hline & & S1 & & & & & \\
\hline & & S3 & & & & & \\
\hline
\end{tabular}

in the channel fills probably records channel bank in stability and slumping.

\section{SB: SANDY BEDFORMS (FIGURE 8)}

Sandy bedforms consist of facies association S1 and S3. They have sharp bases and are often eroded by channels. Sand bedforms are usually about $1 \mathrm{~m}$ to $2 \mathrm{~m}$ thick. They are intercalated with overbank elements.

Sand bedforms record intra-channel deposition. They were probably produced by migrating ripples within the channel.

\section{DA: DOWNSTREAM- AGGRETION MAGROFORMS (FIGURE 9)}

Downstream accretion macroforms comprise facies associations G1, S1 and S3. Their geometry is sheet-like. Downstream accretion macroform thicknesses are up to $5 \mathrm{~m}$, and widths vary between $20 \mathrm{~m}$ and $40 \mathrm{~m}$.

Downstream accretion macroforms record chan- nel deposition.

FF: OVERBANK FINE (FIGURE 9)

This element consists of sheet-like units of tens of meters in lateral extent; it comprises facies associations F1 and F2, and presents vertical facies variability, reflecting the fact that the depositional surface was flat and readily susceptible to small changes in depositional processes.

Overbank fine record individual flood events, the presence of desiccation cracks indicate longer term drying out of the floodplain.

\section{Clast composition and provenance}

The results of pebble counts are reported in Table 4. Clast shape is predominantly sub-angular to sub-rounded. Andesite and diorite are the most abundant igneous rock types; quartzite and phyllite are the most metamorphic rock, which occur 

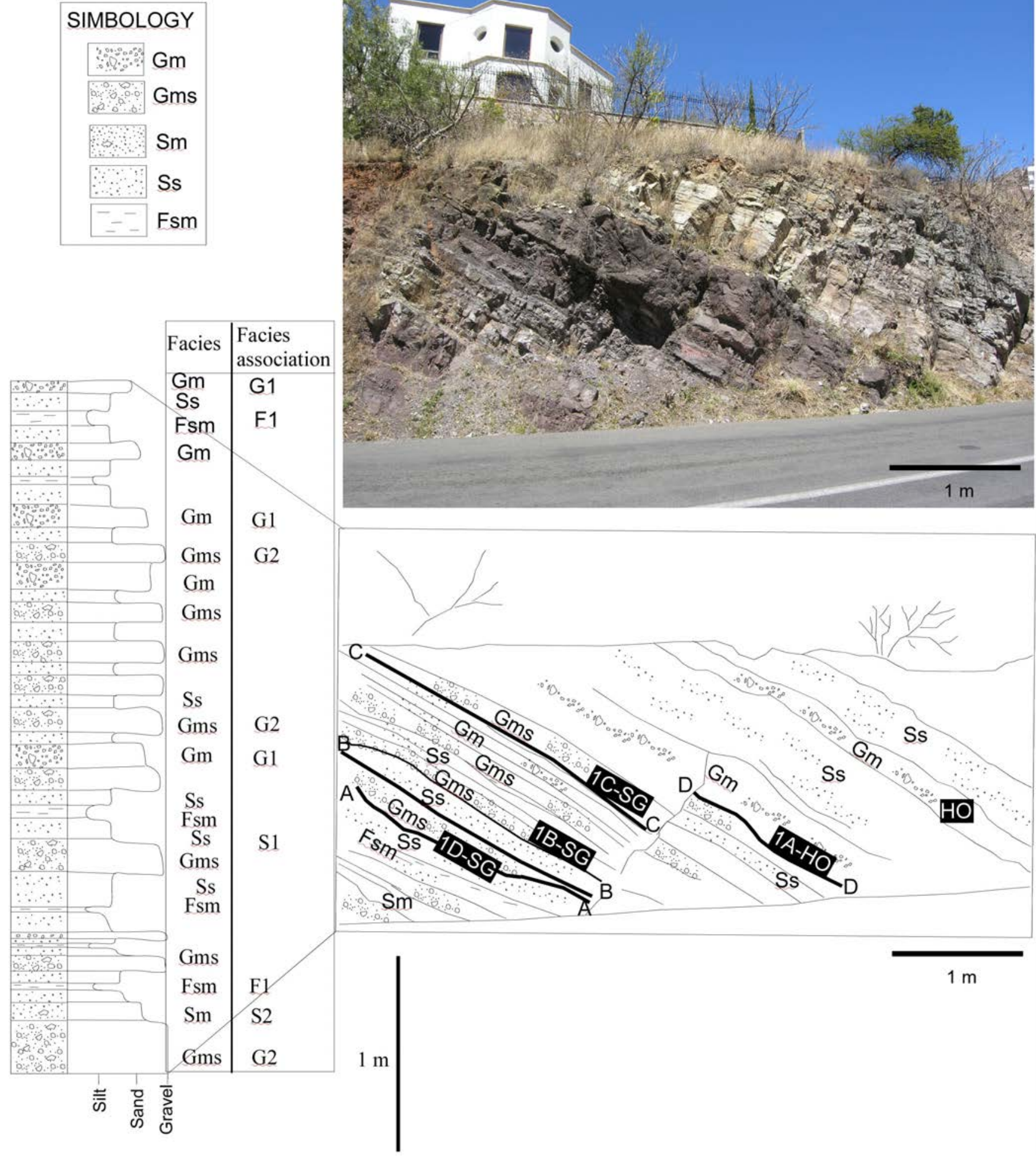

Figure 6 Fourth-order and fifth-order architectural elements of the Guanajuato Conglomerate. HO: Channels (Scour Hollows); SG: sediment gravity flow deposits. Bounding surfaces (1 A-HO, 1B-SG, 1C-SG, 1D-SG ). 


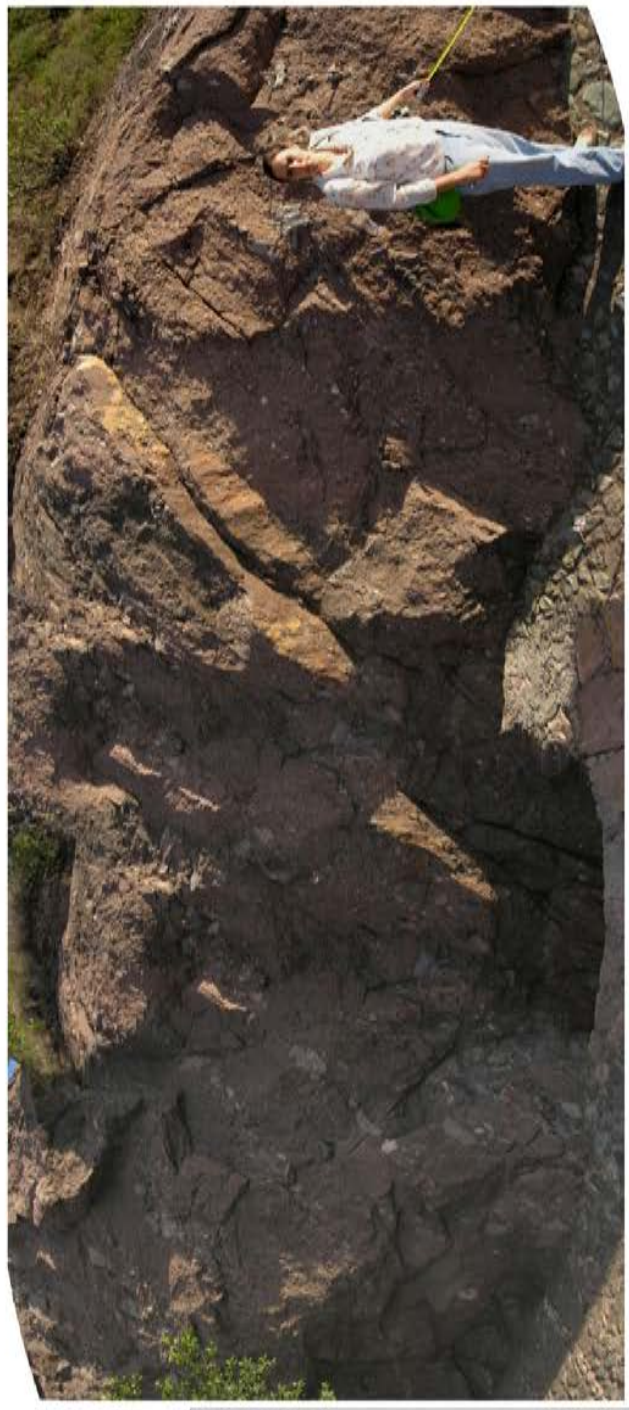

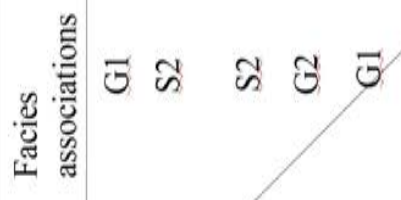

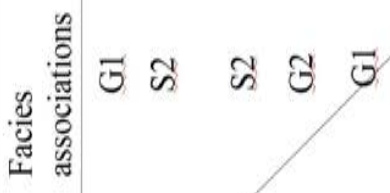

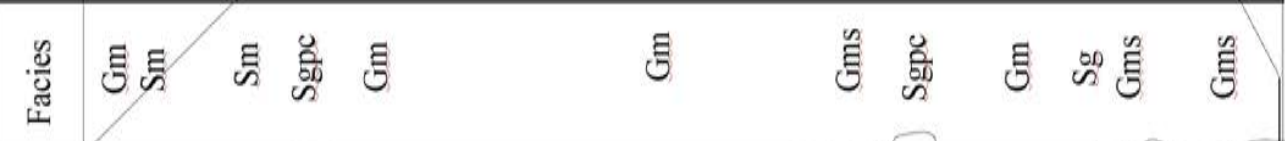

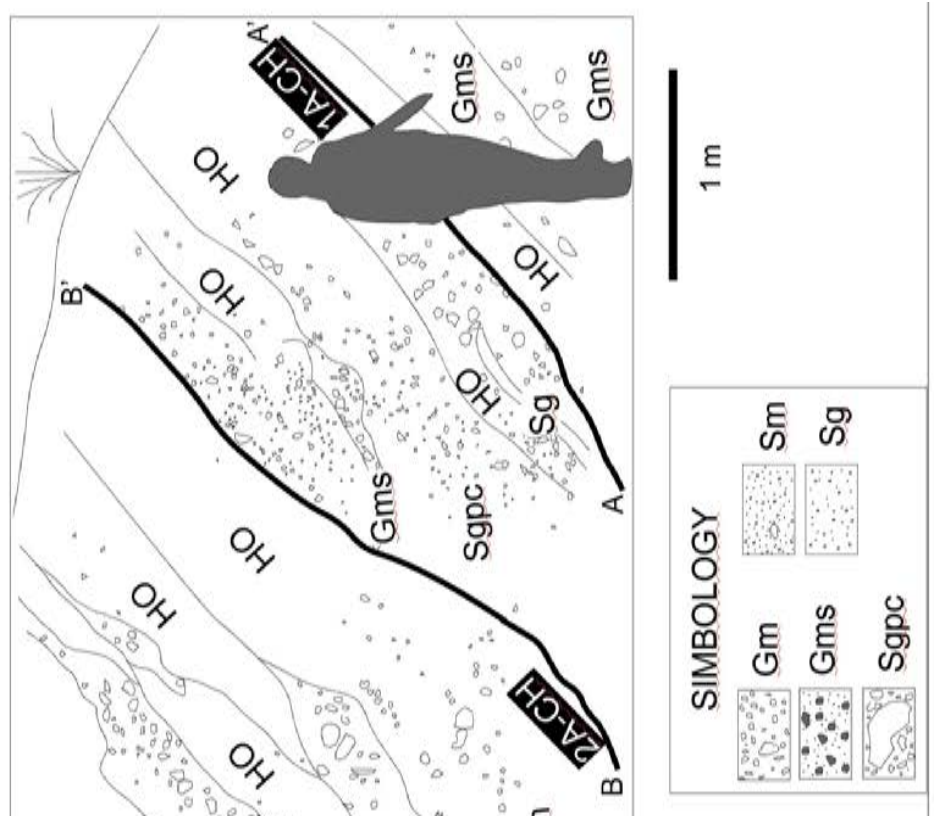

E

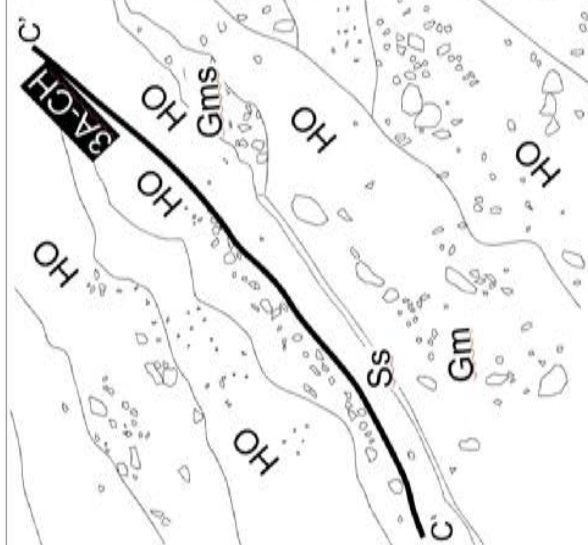

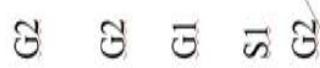




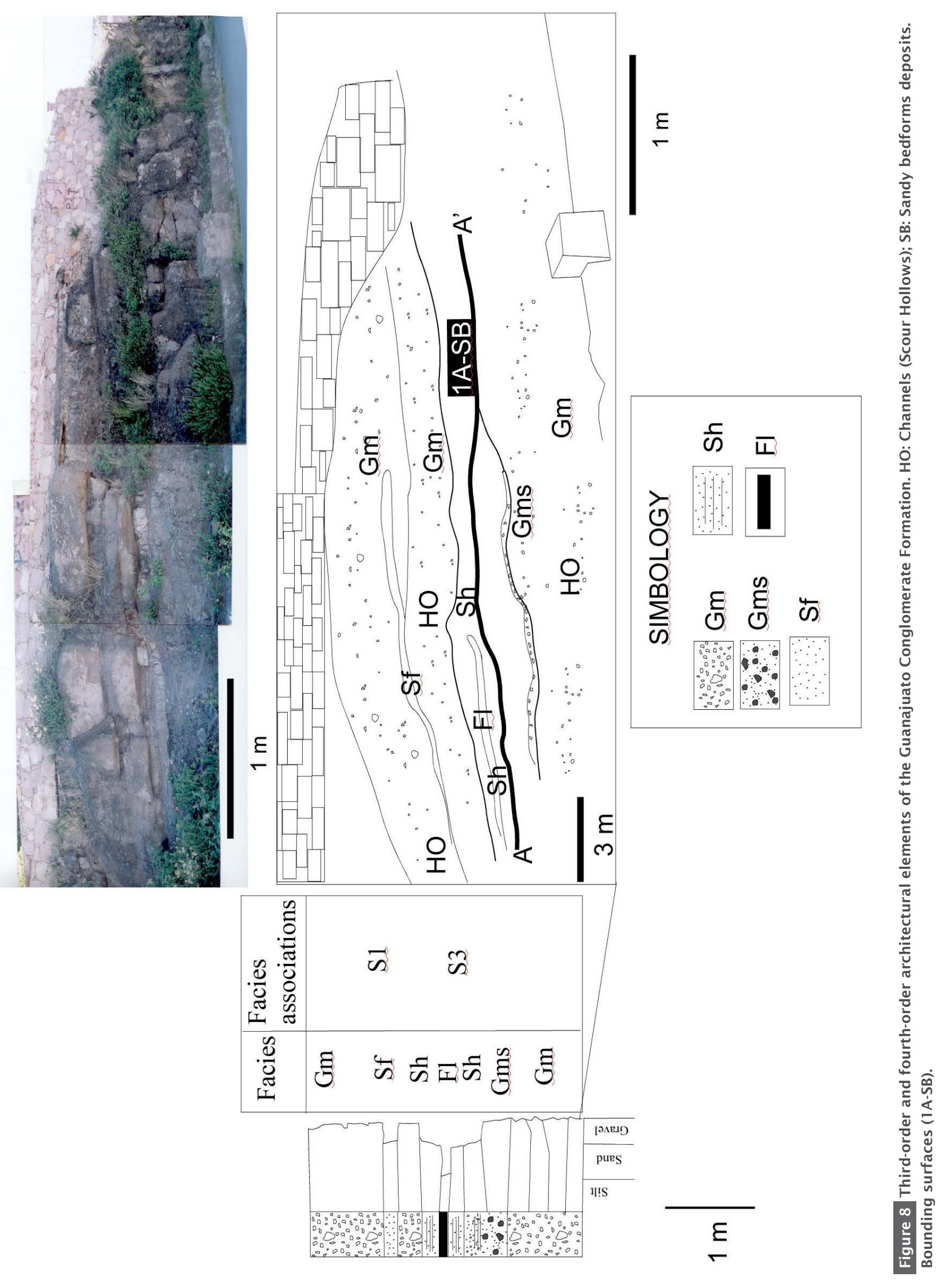




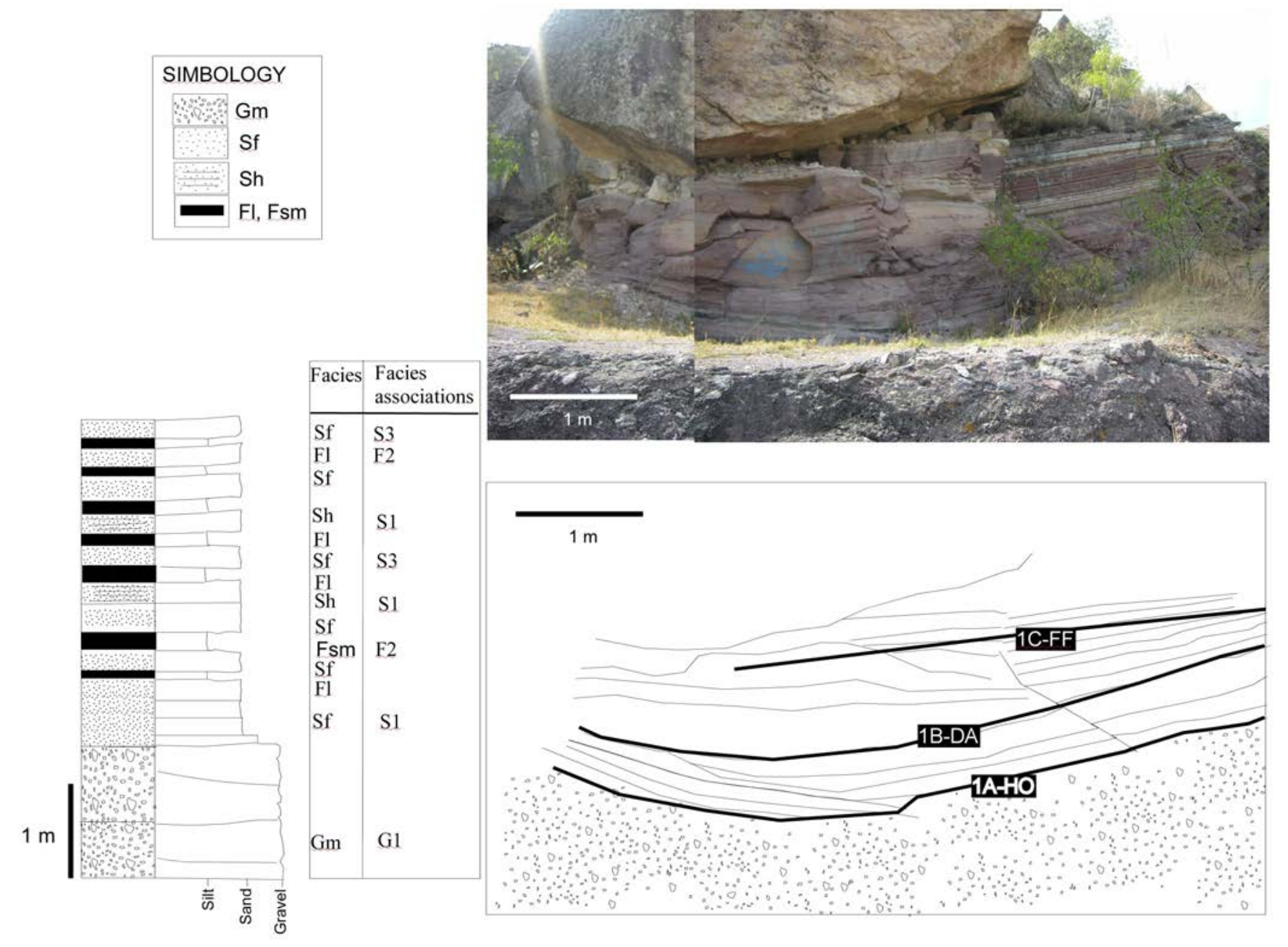

Figure 9 Third-order and fourth-order architectural elements of the Guanajuato Conglomerate. HO: Channels (Scour Hollows); SB: Sandy bedforms deposits. Bounding surfaces (1A-HO, 1B-DA, 1C-FF).

in variable amounts in the Lower Mem-ber of the Guanajuato Conglomerate [(andesite (37.96 $\%$ ), diorite $(21.96 \%)$, phyllite $(16.94 \%)$, quartzite $(9.2 \%)$, granite $(5.6 \%)$, rhyolite $(4.74 \%)$, and sandstone $(3.4 \%)$ ]. Granite and limestone clasts are dominant in the Upper Member [granite $(41.8$ $\%$ ), limestone, (31.57\%), rhyolite $(11.43 \%$ ), andesite $(9.48 \%)$, diorite $(3.72 \%)$, and sandstone, $(2 \%)]$. The Arperos assemblage seems to be the main source of metamorphic rocks for the Guanajuato Conglomerate (Miranda-Avilés et al., 2016). Volcanic rocks apparently are from Mesozoic petrotectonic assemblages. Sedimentary clasts are mainly limestone pebbles from the Arperos Basin assemblage (Omaña et al., 2015). Plutonic rocks are mostly composed of granite derived from exhumed intrusion. The increase of plutonic and sedimentary pebbles in the Upper Member is counterbalanced by a decrease of metamorphic and volcanic clast, which disappears up to the northeast of the study area.

\section{Analysis of paleocurrent directions}

Paleocurrent analyses in the study area (Figure 1) indicate that basin sedimentation underwent two significant sediment transports. The principal flow and sediment transport direction in the Lower 
Table 4. Clast composition of Guanajuato conglomerate.

\begin{tabular}{|c|c|c|c|c|c|c|c|c|c|}
\hline \multicolumn{6}{|c|}{ Lower Member } & \multicolumn{4}{|c|}{ Upper Member } \\
\hline & \multicolumn{3}{|l|}{ Basal Part } & \multicolumn{6}{|l|}{ Top part } \\
\hline $\begin{array}{c}\text { Conglomerate detrital } \\
\text { mode }\end{array}$ & & & & & & & & & \\
\hline Stratigraphic Section & Section 1 & Section 2 & Section 3 & Section 4 & Section 5 & Section 6 & Section 7 & Section 8 & Section 9 \\
\hline Pebble type & $\%$ & $\%$ & $\%$ & $\%$ & $\%$ & $\%$ & $\%$ & $\%$ & $\%$ \\
\hline Sandstones & 4 & 4 & 4 & 3 & 3 & 2 & 2 & 2 & 2 \\
\hline Granite & 6 & 6 & 5 & 6 & 5 & 42 & 41.9 & 41.9 & 41.4 \\
\hline Rhyolites & 4 & 5 & 5 & 4.8 & 4.9 & 11 & 11.9 & 11 & 11.8 \\
\hline Andesites & 37.9 & 38 & 37.9 & 38 & 38 & 9.9 & 9.8 & 9 & 9.2 \\
\hline Diorites & 21.9 & 22 & 22 & 21.9 & 22 & 3.9 & 3.4 & 3.9 & 3.7 \\
\hline Quartzites & 9.3 & 8 & 9.2 & 9.3 & 10.2 & 0 & 0 & 0 & 0 \\
\hline Shallow water limestone & 0 & 0 & 0 & 0 & 0 & 31.2 & 31 & 32.2 & 31.9 \\
\hline Metasediments & 16.9 & 17 & 16.9 & 17 & 16.9 & 0 & 0 & 0 & 0 \\
\hline Total determined pebbles & 100 & 100 & 100 & 100 & 100 & 100 & 100 & 100 & 100 \\
\hline
\end{tabular}

Member was to the SE; in the other hand, the sediment transport direction in the Upper Member was SW, indicating a sediment source to the NNW for the Lower Member and a NNE source for the Upper Member. The different channels geometries distinguished in the sediments were classified as two main simplified types: isolated and amalgamated. The Lower Member show isolated geometries, while the Upper Member has amalgamated geometries (Figure 11). The major bounding erosional surfaces (channels) are interpreted as rapid geomorphic response to tectonic subsidence pulses in the basin boundary fault.

\section{Depositional model}

In the present study, a conceptual model has been constructed to provide an idea about the paleogeography and environments of deposition of the Guanajuato Conglomerate (Figure 10). Internal sedimentary structures, boundary conditions, facies, their interrelationships, and facies association suggest deposition under channelized condition in moderately sinuous stream in an alluvial fan (Lower Member) to fluvial plain (Upper Member and Losero Formation) setting (Figure 11). The sedimentary facies, sequence, and their vertical changes in facies association indicate a progressive decrease in coarse clastics and an increase in fine clastics. The evidence for this comes from the fining-upward channel-fill sequences which were built up by numerous flooding events as indicated by the desiccated mud drapes and internal erosion surfaces. The analysis of facies types and facies assemblages in the Guanajuato Conglomerate suggests an alluvial fan and fluvial depositional environments dominated by streams. Two identified informal members (Lower and Upper) of the Guanajuato Conglomerate resemble characteristics of the facies associations (G1, G2, S1, S2, S3, F1 and F2) in an alluvial fan fluvial depositional environment. The Clast-supported to matrix-supported Gravel Bed (G1, G2) interbedded with sandstones beds (S1, S3 and F1, F2) form the Lower Member of the sequence. The Upper Member is characterized by alternating beds of clast-supported to fineand coarse-grained sandstone to siltstone (G1, S1, $\mathrm{S} 3, \mathrm{~F} 1$ and F2). The abundance of coarse-grained facies and the relative scarcity of mud-dominated facies in this association suggest that deposition occurred primarily in a bedload-dominated stream 
system (Schumm, 1977; Galloway, 1981). Deposits of this facies association commonly display fining and coarsening upwards sequences that are less than $30 \mathrm{~m}$ thick. The vertical transition from the Lower Member to the Upper Member of the Guanajuato Conglomerate reflects a marked change in the fluvial architecture. It is observed that he Lower Member is represented by channels $(\mathrm{CH})$ and channels fills $(\mathrm{HO})$, sediment gravity-flow deposits (SG), sandy bedforms, and overbank fine (FF), while that Upper Member is dominated by channels fills (HO) (Figure 11). Regionally, the proportion of overbank sediments increases to the south, where the sediments con-sist of dominantly mudstone and thinly, bedded sandstone. The average grain size and proportion of sandstone in outcrop increases up section and eastward.

\section{Conclusions}

Siliciclastic sediments of the Lower Member of the Guanajuato Conglomerate were deposited in alluvial fans, while the deposits of the Upper Member were deposited in a braided fluvial system. Fluvial braided deposits are gradational with alluvial-fan deposits. The change from alluvial fan to fluvial environments is interpreted as a relatively sudden tectonic reorganization. The stacking of multiple stories within a sheet or channel form suggests deposition under aggrading conditions. Stories form because of shifting or avulsion of active stream tracts, probably during major flood events and space accommodation (e.g. Subsidence) (Friend et al., 1979). Erosion and deposition within a story may record a single large event or several smaller events. Sedimentary structures and coarse grain size indicate that streams were characterized by mobile channels of inferred low sinuosity. Mudstone drapes within braidplain deposits suggest episodic and presumably ephemeral flooding. Coarsening-upward sequences (Lower Member of the Guanajuato Conglomerate) record progressively higher energy depositional processes (sheetflood to braided channel) and progradation of the alluvial fan (Heward, 1978). Fining-upward sequences (Upper Member) record progressively lower energy depositional processes (braided channel to stream-flood) related to migration of channels within of the braided fluvial system. These sequences may form in response to changing local base level or climatic conditions (Heward, 1978), both of which result in gradual fan abandonment or diminution of sediment supply from the uplifted blocks. The vertical evolution of, and controls on the stratigraphic architecture are consistent with previous upstream fluvial stratigraphic models that suggest that an upward decrease of channel-belt abundance. Paleocurrent analysis indicates that regional paleo-slope was toward the west or southwest of the study area and that siliciclastic detritus was derived from an ancestral uplifted range front. Conglomerate detrital modes of the Guanajuato Conglomerate consistently record an increasing input from plutonic and sedimentary rocks reflecting the very fast exhumation of uplifted blocks during the Oligocene and an abrupt change in the ratio between plutonic/volcanic rocks in the source area in the Eocene. A break in this volcanic-enriching trend is recorded in the upper Lower Member of the Guanajuato Conglomerate, reflecting a source area reorganization during the Oligocene. Therefore, the Lower Member of the Guanajuato Conglomerate records the effects of the erosion of Mesozoic petrotectonic assemblages. Clastic material in the formation was derived from a number of different source rock types exposed during the latter part of the Laramide Orogeny. The overall increase of preservation of overbank deposits upward is consistent with previous models of basin-scale upstream fluvial stratigraphic architecture, but the along-strike persistence and stacking of channel belts directly adjacent to a point source provides unique insight into the basin-scale stratigraphic evolution of upstream fluvial systems. The coarsening and thickening-upward pattern and southeastward progradation, coupled with the variable proportions of sandy bedforms, overbank facies, channel size, and degree of channel abandonment 
in the Guanajuato Conglomerate reflect a distal through proximal fluvial braided environment.

\section{Acknowledgment}

This research was conducted with the financial support of DINPO-University of Guanajuato, Project 000044/09. Many thanks to Arturo Martín Barajas and Claudia C. Mendoza Rosales, whose critical reviews greatly improved the quality of this paper.

\section{References}

Aguirre-Díaz, G.J., Ferrari, L., Nelson, S.A., Carrasco-Núñez, G., López-Martínez, M., Urrutia-Fucugauchi, J., 1998, El cinturón volcánico mexicano: un nuevo proyecto multidisciplinario, Unión Geofísica Mexicana: 18, 131-138.

Andrews, E.D., 1979, Scour and fill in a stream channel, East Fork River, western Wyoming: United States Geological Survey Professional Paper, 1117 p.

Aranda-Gómez, J.J., Aranda-Gómez, J.M., NietoSamaniego, A.F., 1989, Consideraciones acerca de la evolución tectónica durante El Cenozoico de La Sierra de Guanajuato y la parte meridional de la Mesa Central: Universidad Nacional Autónoma de México, Revista del Instituto de Geología, 8 (1), 33-46.

Aranda-Gómez, J.J., McDowell, F.W., 1998, Paleogene extension in the southern basin and range province of México: Syndepositional tilting of Eocene red beds and Oligocene volcanic rocks in the Guanajuato mining district: International Geology Review, 40, 116-134.

Aranda-Gómez, J.J., Godchaux, M.M., AguirreDíaz, G.J., Bonnichsen, B., MartínezReyes, J., 2003, Three superimposed volcanic arcs in the southern Cordillera from the Early Cretaceous to the Miocene, Guanajuato, Mexico, in Geologic transects across Cordilleran Mexico: guidebook for field trips of the 99th Annual Meeting of the Cordilleran Section of the Geological Society of America, México. Field trip 6. Universidad Nacional Autónoma de México, Instituto de Geología, Publicación Especial 1, 123-168 .

Blair, T.C., 1999 Alluvial-fan and catchment initiation by rock avalanching, Owens Valley, California: Geomorphology, 28, 201-221.

Botero-Santa, P.A., Alaniz-Álvarez, S.A., NietoSamaniego, A.F., López-Martínez, M., Levress, G., Xu, S., Ortega-Obregon, C., 2015, Origen y desarrollo de la cuenca El Bajío en el sector central de la Faja Volcánica Transmexicana: Revista Mexicana de Ciencias Geológica 32 (1), 84-98.

Bull, W. B., 1972, Recognition of alluvian fan deposits in the stratigraphic record, in Rigby, J.K., Hamblin, W.K. (eds.), Recognition of Ancient Sedimentary Environments, Special Publication Society of Economic Paleontologists and Mineralogists, Tulsa, 16, 63-83.

Cerca-Martínez, L.M., Aguirre-Díaz, G.J., LópezMartínez, M., 2000, The geologic evolution of the southern Sierra de Guanajuato, México: A documented example of the transition from the Sierra Madre Occidental to the Mexican Volcanic Belt: International Geology Review, 42, 131-151.

Costa, J.E., 1988, Rheologic, geomorphic, and sedimentologic differentiation of water floods, hyperconcentrated flows, and debris flows, in Baker, V.R., Kochel, K.C., Patton, P.G. (eds.), Flood Geomorphology: USA, John Wiley and Sons, 113-122.

Crowell, J.C., 1955, Directional current structures from the prealpine flysch, Switzerland: Geological Society of America Bulletin, 66, 1351-1384.

Dasgupta, P., 2007, Facies characteristics of Talchir Formation, Jharia Basin, India: Implications 
for initation of Gondwana sedimentation: Sedimentary Geology, 185, 59-78.

Dávila-Alcocer, V.M., Martínez- Reyes, J., 1987, Una edad Cretácica para las rocas basales de la Sierra de Guanajuato, in Simposio sobre la geología de la Sierra de Guanajuato: Resúmenes, México, Instituto de Geología, UNAM, 19-20.

Echegoyen-Sánchez, J., Romero-Martínez, S., Velázquez-Silva, S., 1970, Geología y yacimientos minerales de la parte central del distrito minero de Guanajuato: Boletín Consejo de Recursos Minerales no renovables, 75, 1-35.

Edwards, J.D., 1955, Studies of some early Tertiary red conglomerates of Central Mexico: U.S. Geology Survey Professional, 264, 153-185.

Ferrari, L., López-Martínez, M., Aguirre-Díaz, G.J., Carrasco-Núñez, G., 1999, Space-time patterns of Cenozoic arc volcanism in Central México: From Sierra Madre Occidental to Mexican Volcanic Belt: Geology, 27(4), 303-306.

Ferrusquía-Villafranca, I., 1987, Reubicación geocronologíadelConglomeradoGuanajuato basada en nuevos mamíferos (resumen), in $\mathrm{El}$ programa, resúmenes y guía de excursión del simposio sobre la geología de la región de la sierra de Guanajuato, Guanajuato: Universidad Nacional Autónoma de México, Instituto de Geología, 21-23.

Friend, P.P., Slater, M.J., Williams, R.C., 1979, Vertical and lateral building of river sandstone bodies, Ebro basin, Spain: Journal of the Geological Society of London, 136, 39-46.

Galloway, W.E., 1981, Depositional architecture of Cenozoic Gulf Coastal plain fluvial systems, in Ethridge, F.G., Flores, R.M. (eds), Recent and ancient nonmarine depositional environments: models for exploration, Society of Economic Paleontologists and Mineralogists Special Publication, 31,
127-155.

Gómez-Tuena, A., Orozco-Esquivel, M.T., Ferrari, L., 2005, Petrogénesis ígnea de la Faja Volcánica Transmexicana: Boletín de la Sociedad Geológica Mexicana, 57(3), 227-283.

Guiza, R., 1949, Estudio geológico del Distrito Minero de Guanajuato: Boletín (Instituto Nacional para la Investigación de Recursos minerales), 22-75.

Harms, J.C., Southard, J.B., Walker, R.G., 1982, Structures and sequences in clastic rocks: Society for Sedimentary Geology (SEPM), Short Course Notes, 9, 1-249.

Hein, FJ., 1982, Depositional mechanisms of deep-sea coarse clastic sediments, Cap Enrage Formation, Quebec: Canadian Journal Earth Science, 19, 267-287.

Heward, A.P., 1978, Alluvial fan sequence and mega sequence models with examples from Westphalian D-Stephanian B coalfields, Northern Spain: Sedimentology, 25, 451-488.

Iverson, R.M., Reid, M.E., LaHusen, R.G., 1997, Debris-flow mobilization from landslides: Review Earth Planet Science, 25, 85-138.

Jo, H.R., Rhee, C.W., Chough, S.K., 1997, Distinctive characteristics of a streamflowdominated alluvial fan deposit: Sanghori area, Kyongsang Basin (Early Cretaceous), southeastern Korea: Sedimentary Geology, 110, 51-79.

Jones, B.G., Rust, B.R., 1983, Massive sandstone Facies in the Hawkesbury Sandstone, a Triassic fluvial deposit near Sydney, Australia: Journal Sedimentary Petrology 53, 1249-1259.

Lapierre, H., Ortíz, L.E., Abouchami, W., Monod, O., Coulon, C., Zimmermann, J.L., 1992, A crustal section of an intra-oceanic island arc: the Late Jurassic-Early Cretaceous Guanajuato magmatic sequence, Central México: Earth Planetary Science Letters, 
108, 61-77.

Lara-Hernández, E., 1985, Cartografía geológica del área NW, Hoja Aldama, F14C53, Escala 1:50,000, Guanajuato: La Paz, Universidad Autónoma de Baja California Sur, Thesis, 79 p.

Martini, M., Mori, L., Solari, L., Centeno-García, E., 2013, Sandstone provenance of the Arperos Basin (Sierra de Guanajuato, Central Mexico): Late Jurassic-Early Cretaceous back-arc spreading as the foundation of the Guerrero-terrane: The Journal of Geology, 119, 597-617.

McBride, E.F., 1962, Flysch and associated beds of the Martinsburg Formation (Ordovician) Central Appalachians: Journal of Sedimentary Petrology, 32, 39-91.

McCabe, P.J., 1977, Deep distributary channels and giant bedforms in the Upper Carboniferous of the Central Pennines, northern England: Sedimentology, 24, 271-290.

Miall, A.D., 1977, A review of the braided river depositional environment: Earth Science Review, 13, 1-62.

Miall, A.D., 1978, Lithofacies types and vertical profile models in braided river deposits: A summary, in Miall, A.D. (ed.), Fluvial Sedimentology: Canadian Society Petrology Geology Memoir, 5, 597-604.

Miall, A.D., 1996, The Geology of Fluvial Deposits: Sedimentary Facies, Basin Analysis and Petroleum Geology: Berlin Heidelberg New Cork, Springer-Verlag, 565 p.

Miranda-Avilés, R., Puy-Alquiza, M.J., Omaña, M.J., Loza-Aguirre, I., 2016, Los depósitos clásticos pos-Laramide de la Sierra de Guanajuato: Implicaciones de su composición en la evolución tectono-sedimentaria y paleogeográfica: Estudios Geológicos, 72 (2), $1-19$.

Mutti, E., Davoli, G., Tinterri, R., Zavala, C., 1996, The importance of ancient fluviodeltaic systems dominated by catastrophic flooding in tectonically active basins: Science
Geology Memoir, 48, 233-291.

Nieto-Samaniego, A.F., Alaniz-Álvarez, S.A., Camprubí, A., 2005, La Mesa Central de México: estratigrafía, estructura y evolución tectónica cenozoica: Boletín de la Sociedad Geológica Mexicana, 57 (3), 285-318.

Nieto-Samaniego, A.F., 1992, Fallamiento y estratigrafía cenozoica en la parte suroriental de la Sierra de Guanajuato: Revista Mexicana de Ciencias Geológicas, 9 (2), 146-155.

Omaña, L., Miranda-Avilés, R., Puy-Alquiza, M.J., 2015, Berriasian-early Valanginian calcareous shallow-water facies from the Arperos Basin: A proposal from the foraminiferal assemblage of the clasts of the Guanajuato Conglomerate, central Mexico: Boletín de la Sociedad Geológica Mexicana, 67(1), 45-57.

Orozco, R., 1921, La Industria Minera de México: Distrito de Guanajuato. Secretaria de Industria, Comercio y Trabajo: México, Departamento de exploraciones y Estudios geológicos, $163 \mathrm{p}$.

Ortiz-Hernández, L.E., Choidi, M., Lapierre, H., Monod, O., Calvet, P., 1992, El arco intraoceánico alóctono (Cretácico Inferior) de Guanajuato, características petrográficas, geoquímicas, estructurales e isotópicas del complejo filoniano y de las lavas basálticas asociadas. Implicaciones geodinámicas: Universidad Nacional Autónoma de México, Revista del Instituto de Geología, 9(2), 126-145.

Pierson, T.C., Costa, J.E., 1987, A rheologic classification of subaerial sediment-water flows, in Costa, J.E., Wieczorek, G.F. (eds.), Debris Flows/Avalanches: Process, Recognition, and Mitigation: Reviews in Engineering Geology, Geological Society: American, 7, 1-12.

Randall, J.A., Saldaña, A.E., Clark, K.F., 1994, Exploration in a volcano-plutonic center at Guanajuato, Mexico: Economy Geology, 89, 1722-1751. 
Ricci-Lucchi, F., 1995, Sedimentographica: Photographic atlas of sedimentary structures: U.S.A., Columbia University Press, 251 p.

Rust, B.R., 1978, A classification of alluvial channel systems, in Miall, A.D. (ed), Fluvial Sedimentology: Calgary, Canadian Society Petroleum Geologists Memoir, 187-198.

Rust, B.R., Koster, E.H., 1984, Coarse alluvial deposits, in Walker, R.G. (ed), Facies models: Canada, Geoscience Canadian, 53-69.

Schulze-Ziehl, 1953, Observaciones geológicas y petrogénicas en el mineral de Guanajuato, con referencia especial al "Losero": Servicio Geológico Mexicano, archivo técnico, Clave 1153 SCRG0001.

Schumm, S.A., 1977, The fluvial system: New York, John Wiley and Sons, 338 p.
Scott, K.M., Vallance, J.W., Pringle, P.T., 1995, Sedimentology, behavior, and hazards of debris flows at Mount Rainier: Washington, US Geology Survey Professional Paper, 106 p.

Sohn, Y.K., 1999, Rapid development of gravelly high-density turbidity currents in marine Gilbert-type fan deltas, Loreto Basin, Baja California Sur, Mexico. Sedimentology, 46, 757-761.

Tardy, M., Lapierre, H., Bourdier, J.L., Coulon,C., Ortiz-Hernández, L.E., Yta, M., 1992, Intraoceanic setting of the western Mexico Guerrero Terrane implications for the pacific Tethys geodynamic relationships during the Cretaceous: Universidad Nacional Autónoma de México, Revista del Instituto de Geología, 10(2), 118-128. 